\title{
Editorial \\ NONLINEAR DYNAMICS AND THEIR APPLICATIONS TO ENGINEERING SCIENCES
}

JOSÉ MANOEL BALTHAZAR

Received 23 August 2005; Accepted 23 August 2005

Copyright (c) 2006 José Manoel Balthazar. This is an open access article distributed under the Creative Commons Attribution License, which permits unrestricted use, distribution, and reproduction in any medium, provided the original work is properly cited.

This special issue of Mathematical Problems in Engineering (MPE) contains papers presented in the scientific event "Conference on Nonlinear Dynamics," held in Kharkov, Ukraine, September 14-16, 2004 (ND-KPI 2004).

We hope that this special issue will contribute to the progress of applications on nonlinear dynamics and control and the growing field at the intersection point of applied mathematics and applied science and modern technologies.

Data and information appearing in this publication are only for scientific information; the editors are not responsible for any injury or damage resulting from use or reliance.

José Manoel Balthazar 


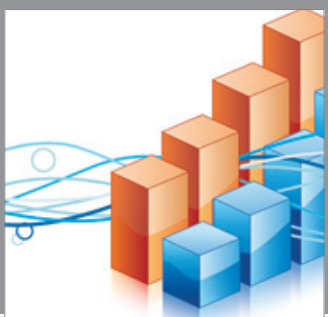

Advances in

Operations Research

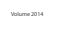

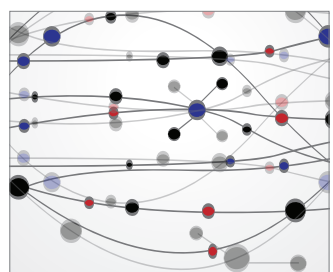

\section{The Scientific} World Journal
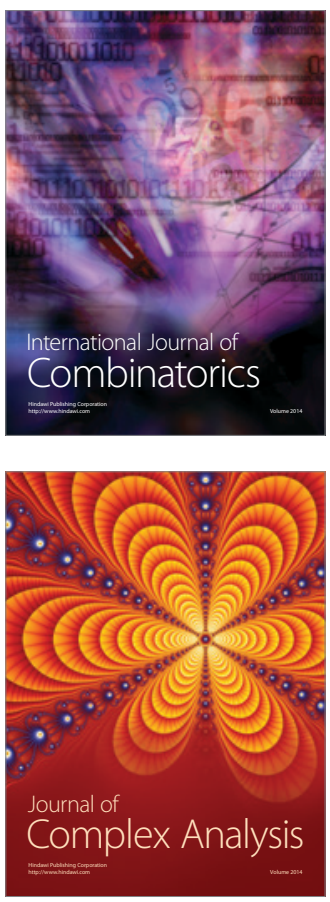

International Journal of

Mathematics and

Mathematical

Sciences
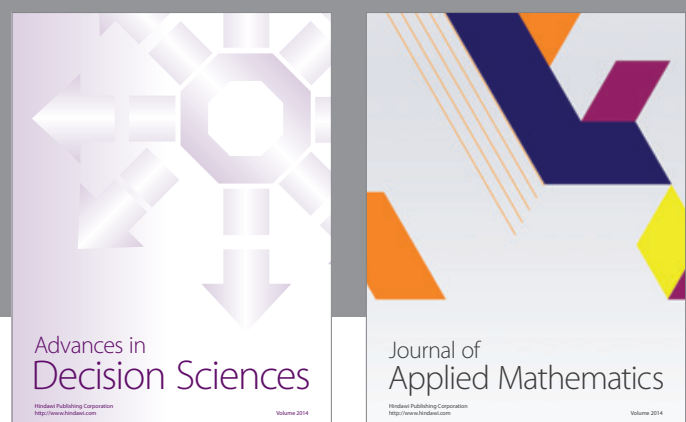

Journal of

Applied Mathematics
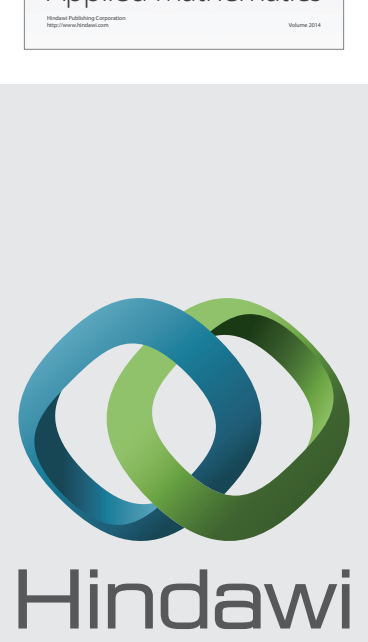

Submit your manuscripts at http://www.hindawi.com
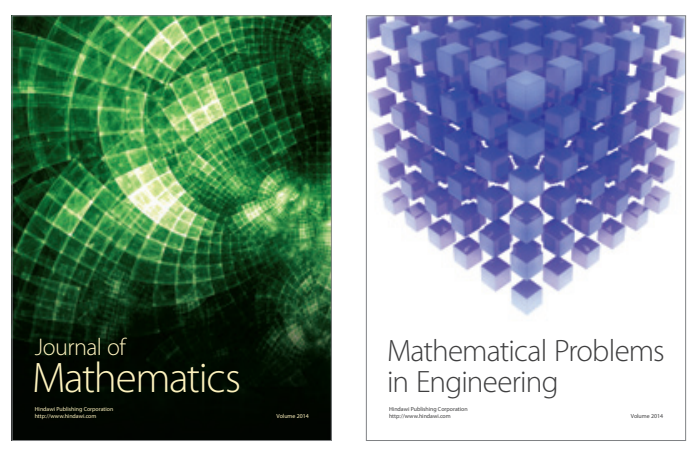

Mathematical Problems in Engineering
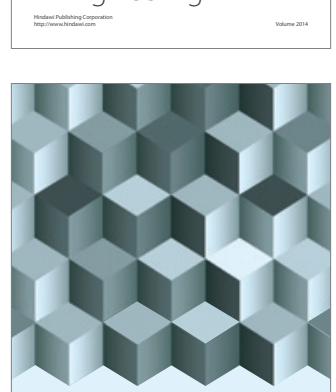

Journal of

Function Spaces
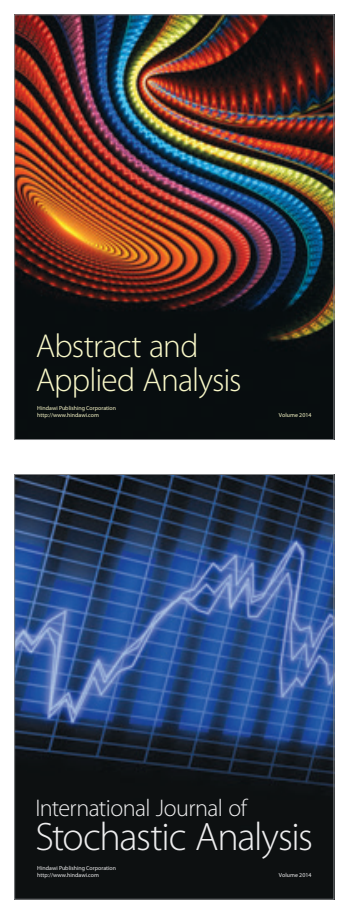

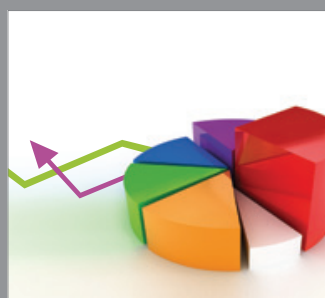

ournal of

Probability and Statistics

Promensencen
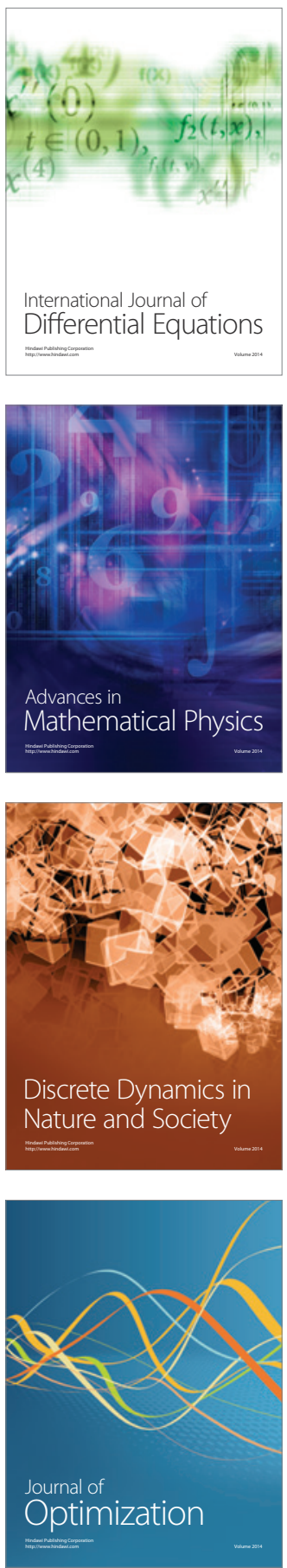